\title{
Presence of peripheral-type benzodiazepine binding sites on human erythrocyte membranes
}

\author{
James M.M. Olson, Brian J. Ciliax, William R. Mancini and Anne B. Young * \\ Departments of Pharmacology, Neurology and The Neuroscience Program, University of Michigan, Ann Arbor, MI 48104, U.S.A.
}

Received 22 April 1988, accepted 3 May 1988

\begin{abstract}
A nanomolar affinity peripheral-type benzodiazepine binding site is described in human erythrocyte membranes. $\left[{ }^{3}\right.$ H]PK 11195 is displaced from this binding site by unlabeled drugs with the rank order PK $11195>$ Ro 5-4864 > flunitrazepam $\gg$ clonazepam. Neither GABA nor a non-hydrolyzable analog of GTP have an effect on binding parameters. These data provide evidence that a peripheral-type benzodiazepine binding site, pharmacologically similar to the intracellular binding site described in other tissues, is present in the plasma membrane of human erythrocytes.
\end{abstract}

Benzodiazepines (peripheral); PK 11195; Erythrocytes; (Plasma membrane)

\section{Introduction}

Peripheral-type benzodiazepine binding sites are characterized by primary distribution in tissues outside the central nervous system, nanomolar affinity for the ligands Ro 5-4864 and PK 11195, and lack of affinity for clonazepam. In contrast, central benzodiazepine receptors are located primarily in the central nervous system where they mediate the sedative-hypnotic, anxiolytic and anticonvulsant actions of clinically useful benzodiazepines. The central receptor does not recognize Ro 5-4864 or PK 11195 at nanomolar concentrations, but demonstrates high affinity for clonazepam. Both peripheral-type benzodiazepine binding sites and central receptors bind flunitrazepam and diazepam.

The anatomic distribution of peripheral-type benzodiazepine binding sites has been widely

\footnotetext{
* To whom all correspondence should be addressed: Neuroscience Laboratory Building, 1103 E. Huron, Ann Arbor, MI 48104-1687, U.S.A.
}

studied. Peripheral-type binding sites have been localized to a number of solid tissues in rat (Anholt et al., 1985). Additionally, sites have been described on rat peritoneal mast cells and platelets (Taniguchi et al., 1980; Wang et al., 1980). Peripheral sites have been described in a number of other mammals where marked interspecies differences have been found (Cymerman et al., 1986). In human tissue, peripheral-type benzodiazepine binding has been demonstrated in brain, kidney, iris and platelets (Pazos et al., 1986; Doble et al., 1987; Valtier et al., 1987; Benavides et al., 1984). Peripheral-type agonists cause chemotaxis of human monocytes, possibly mediated by high affinity peripheral-type benzodiazepine binding sites present on the cells (Ruff et al., 1985).

The subcellular location of the peripheral-type benzodiazepine binding sites has been a source of controversy since the site was described. Braestrup and Squires (1977) demonstrated that Ro 5-4864 displaceable $\left[{ }^{3} \mathrm{H}\right]$ diazepam binding in rat kidney homogenates sedimented with mitochondria. Mitochondrial location of the binding sites has also been suggested for peripheral-type benzodi- 
azepine binding sites in rat adrenal (Anholt et al., 1986) and guinea pig (Weissman et al., 1984), rat (Basile and Skolnick, 1986), human and cat brain (Doble et al., 1987). [ $\left.{ }^{3} \mathrm{H}\right]$ Ro 5-4864 binding was shown to localize to the same fraction as nuclear membrane in rat brain (Marangos et al., 1982; Schoemaker et al., 1983; Doble et al., 1987) and rat kidney (Schoemaker et al., 1983). In canine myocardium, $\left[{ }^{3} \mathrm{H}\right] \mathrm{PK} 11195$ binding distributed to sarcolemma and ryanodine-sensitive sarcoplasmic reticulum (Doble et al., 1985).

In this study, a nanomolar affinity peripheraltype benzodiazepine binding sites is characterized in human erythrocytes. Because these cells lack nuclei, mitochondria, and endoplasmic reticulum, it is likely that the binding site is located on the plasma membrane.

\section{Materials and methods}

\subsection{Materials}

$\left[{ }^{3} \mathrm{H}\right] \mathrm{PK} 11195(75.2 \mathrm{Ci} / \mathrm{mmol})$ and $\left[{ }^{3} \mathrm{H}\right]$ tyramine $(39.1 \mathrm{Ci} / \mathrm{mmol})$ were obtained from New England Nuclear Corporation (a subsidiary of Dupont, Boston, MA). PK 11195 was a gift from Dr. G. Le Fur, Pharmuka (Gennevilliers, France). Benzodiazepines were donated by Dr. P. Sorter of Hoffman-La Roche, (Nutley, NJ). Polyethylenimine was purchased from Aldrich and GMP-PNP from Boehringer Mannheim (W. Germany). All others reagents were from Sigma. PK 11195 is 1-(2-chlorophenyl)-N-methyl-N-(1-methylpropyl)-isoquinoline-3-carboxamide; Ro 5-4864 is 4'chlorodiazepam; GMP-PNP is guanylyl-imidodiphosphate.

\subsection{Membrane preparation}

Human blood was collected in heparinized tubes then immediately centrifuged at $1000 \times g$ for 20 min at $4^{\circ} \mathrm{C}$. Plasma, platelets, buffy coat, and a third of the erythrocyte fraction were carefully aspirated and discarded. In some experiments, the erythrocyte fraction was further purified over columns of 50\% microcellulose (Sigmacell 50), 50\% $\alpha$-cellulose (Bentler et al., 1976). Purified erythro- cytes were lysed and washed in 20 mOsm sodium phosphate buffer and separated from hemoglobin as described by Dodge et al. (1962). For the saturation experiments in fig. $2,2 \mathrm{ml}$ of resuspended erythrocytes were added to $27 \mathrm{ml}$ of lysing buffer (preparation 1). In all other experiments (preparation 2), 4-6 $\mathrm{ml}$ of resuspended erythrocytes were added to $27 \mathrm{ml}$ of lysing buffer. For each experiment, the membranes were washed with four consecutive centrifugations ( $40 \mathrm{~min}$ at 20000 $\times g$ ) in $27 \mathrm{ml}$ lysing buffer. Binding studies were performed on erythrocyte membranes suspended in isotonic phosphate buffered saline immediately following the fourth wash. All buffers were $\mathrm{pH}$ 7.4.

Protein concentrations of membrane preparations were determined by the Bradford assay (Biorad, Richmond, CA).

\section{3. [ ${ }^{3} H J P K ~ 11195$ binding assays}

One millilitre of membrane suspension $(0.35$ $\mathrm{mg}$ protein) was added to $1 \mathrm{ml}$ of incubation buffer containing $\left[{ }^{3} \mathrm{H}\right] \mathrm{PK} 11195$ and competitor drugs or vehicle. The membranes were incubated $90 \mathrm{~min}$ in an ice-water bath. Binding was halted by rapid addition of $4 \mathrm{ml}$ ice cold phosphate buffered saline followed by immediate vacuum assisted filtration through Schleicher and Schuell No. 32 glass fiber filters, pretreated with $0.05 \%$ polyethyleneimine (Hampton et al., 1982). Within $15 \mathrm{~s}$, membranes were washed five times with $4 \mathrm{ml}$ of phosphate buffered saline. Filters were placed in $5 \mathrm{ml} \mathrm{ACS}$ and assayed for tritium by liquid scintillation spectroscopy using a Beckman LS 8100 liquid scintillation counter.

Time course studies were carried out using 1 nM $\left[{ }^{3} \mathrm{H}\right] \mathrm{PK}$ 11195. In competition studies, erythrocyte membranes were incubated with 2.5 nM $\left[{ }^{3} \mathrm{H}\right] \mathrm{PK} 11195$ and increasing concentrations of unlabeled benzodiazepines or PK 11195. All samples contained $0.5 \%$ ethanol. In saturation experiments, increasing concentrations of $\left[{ }^{3} \mathrm{H}\right] \mathrm{PK}$ 11195 were incubated in the presence or absence of $10 \mu \mathrm{M}$ GMP-PNP or $100 \mu \mathrm{M}$ GABA (unlabeled) for $90 \mathrm{~min}$. Non-specific binding was described as binding which occurred in the presence of $10 \mu \mathrm{M}$ unlabeled Ro 5-4864. 


\subsection{Monoamine oxidase assay}

Monoamine oxidase activity was assayed by the method of Wurtman and Axelrod (1963). $\left[{ }^{3} \mathrm{H}\right]$ Tyramine was used as the substrate. Monoamine oxidase A activity was taken to be the clorgyline sensitive counts extractable in toluene.

\section{Results}

\subsection{Membrane purity}

Three of five samples from 20 unlysed erythrocyte preparations were examined microscopically for nucleated cell contamination. In over $70 \%$ of the samples examined, no nucleated cells were detected. In the remaining samples, there were never more than one contaminating cell per $10^{5}$ erythrocytes. Erythrocyte preparations were also assayed at the University of Michigan Medical Center Hematology Laboratories for platelet contamination. Platelets were present at concentra- tions of $1-5 \mu \mathrm{g}$ per sample in the experiments described in the figures. This represents approximately $0.01 \%$ of the total protein assayed $(0.35$ $\mathrm{mg} /$ tube). In samples that were further purified over cellulose columns, platelets accounted for $0.0001 \%$ of the protein assayed.

Clorgyline sensitive monoamine oxidase A activity was absent in human erythrocytes but was abundant in rat liver controls (data not shown).

\subsection{Kinetics of $\left[{ }^{3} \mathrm{H}\right] \mathrm{PK} 11195$ binding}

At a concentration of $1 \mathrm{nM}\left[{ }^{3} \mathrm{H}\right] \mathrm{PK} 11195$, binding to erythrocyte membranes reached equilibrium by $40 \mathrm{~min}$ and remained at equilibrium for at least $240 \mathrm{~min}$ (fig. 1). The initial rate constant $\left(\mathrm{k}_{\text {obs }}\right)$ was $0.3 \mathrm{~min}^{-1}$, calculated from the slope of $\ln \left(B_{e} / B_{e}-B_{t}\right)$ versus time $\left(B_{c}=P K 11195\right.$ binding at equilibrium, $B_{t}=$ PK 11195 binding at time (t), fig. 1 inset, left). Following $120 \mathrm{~min}$ of incubation with erythrocyte membranes, $\left[{ }^{3} \mathrm{H}\right] \mathrm{PK}$ 11195 binding was reversed by the addition of 10 $\mu \mathrm{M}$ unlabeled PK 11195. [ $\left.{ }^{3} \mathrm{H}\right] \mathrm{PK} 11195$ binding

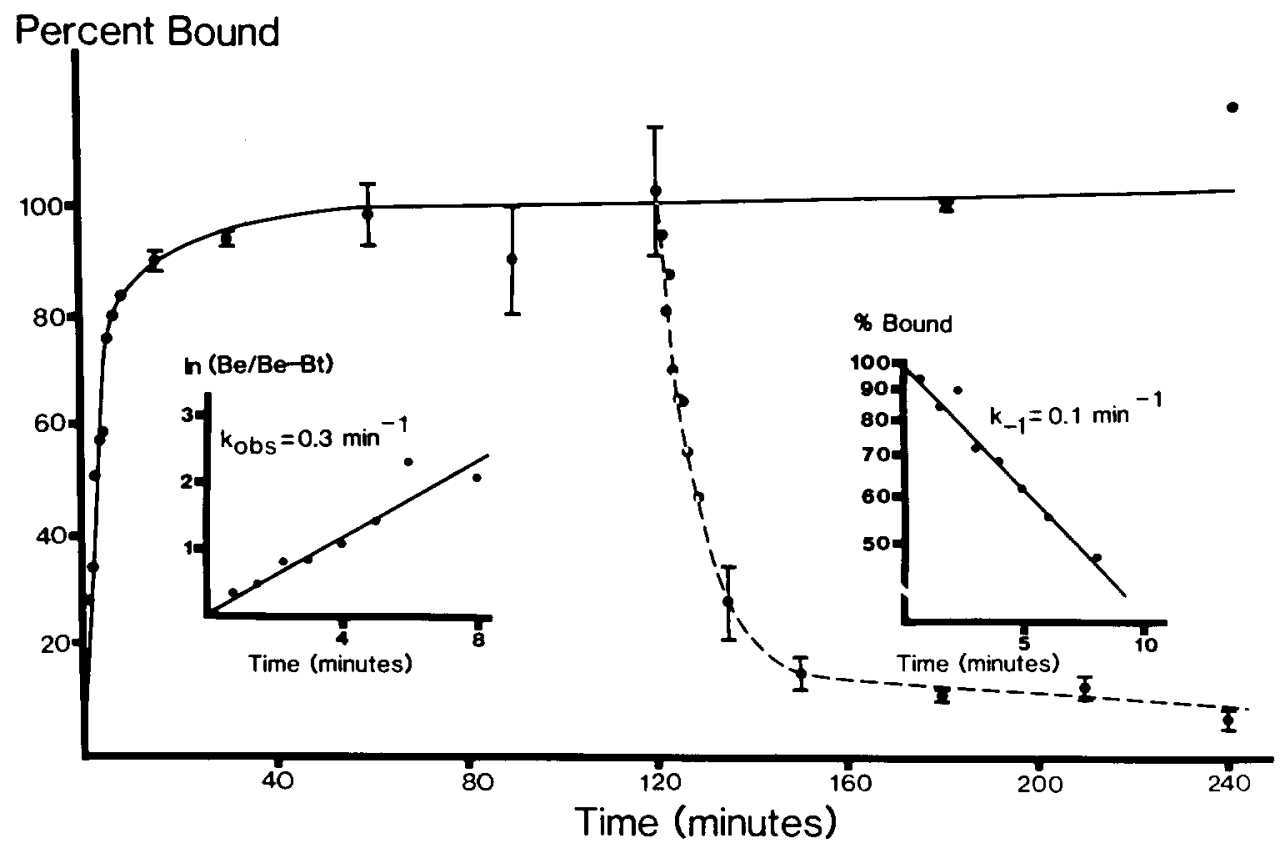

Fig. 1. Time course for $\left[{ }^{3} \mathrm{H}\right] \mathrm{PK} 11195$ binding to erythrocyte membranes. Membranes were incubated with $1 \mathrm{nM}\left[{ }^{3} \mathrm{H}\right] \mathrm{PK} 11195$ at $4^{\circ} \mathrm{C}$ for various times. At $120 \mathrm{~min}, 10 \mu \mathrm{M}$ unlabeled PK 11195 was added to reverse binding (dashed line). Data represent specific binding of three experiments done in triplicate. 


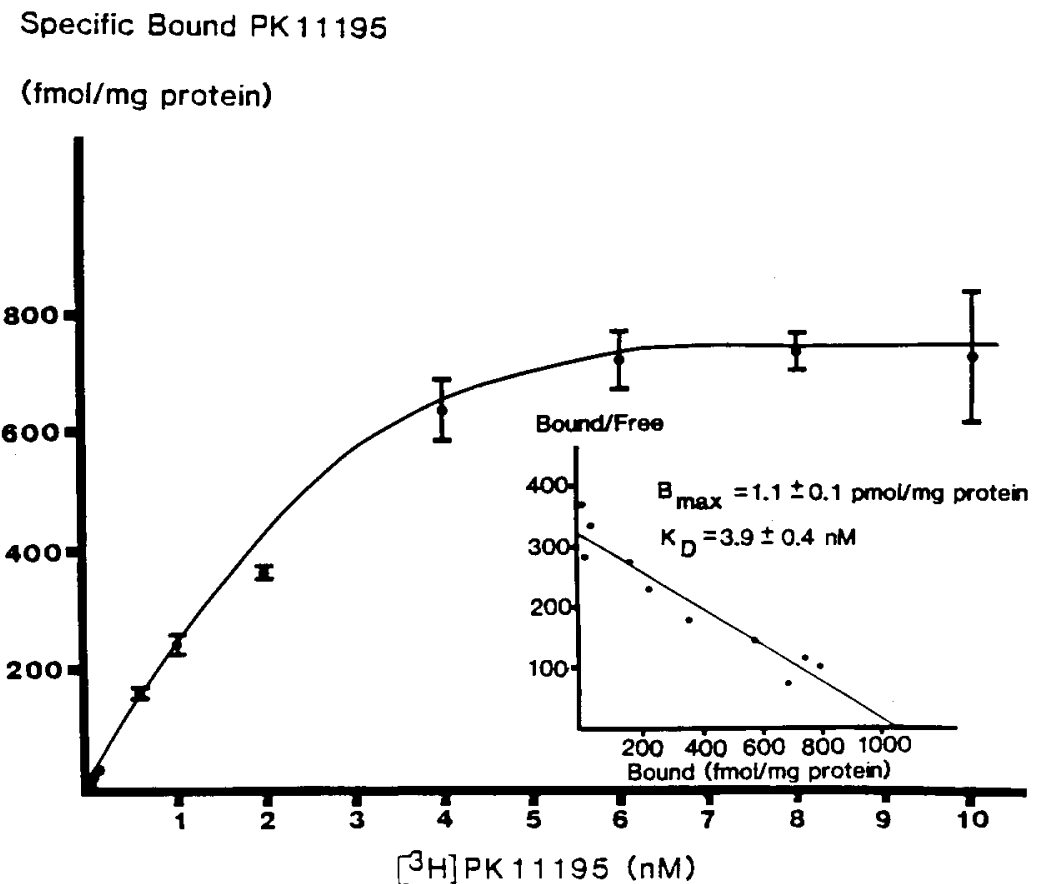

Fig. 2. Saturation isotherm of specific $\left[{ }^{3} \mathrm{H}\right] \mathrm{PK} 11195$ binding to human erythrocyte membranes. Membranes were incubated with 20 $\mathrm{pM}$ to $10 \mathrm{pM}$ to $10 \mathrm{nM}\left[{ }^{3} \mathrm{H}\right] \mathrm{PK} 11195$ for $90 \mathrm{~min}$ at $4{ }^{\circ} \mathrm{C}$. Specific binding represents the difference between total binding and binding in the presence of $10 \mu \mathrm{M}$ unlabeled Ro 5-4864. Inset, Scatchard analysis of saturation isotherm. Data represent the mean of three independent experiments done in triplicate.

dissociated with a $\mathbf{k}_{-1}$ of $0.1 \min ^{-1}\left(\mathbf{k}_{-1}=\right.$ $0.693 /$ half time of dissociation). From these values, a $\mathrm{K}_{\mathrm{D}}$ value of $0.5 \pm 0.7 \mathrm{nM}$ was calculated (when the concentration of $\left[{ }^{3} \mathrm{H}\right] \mathrm{PK} 11195=1 \mathrm{nM}$, $\mathbf{K}_{\mathrm{D}}=\mathbf{k}_{-1} / \mathbf{k}_{+1}$ where $\mathbf{k}_{+1}=\mathbf{k}_{\text {obs }}-\mathbf{k}_{-1}$ ). Nonspecific binding was less than $17 \%$ in all experiments.

Saturation experiments were performed over the range of $20 \mathrm{pM}$ to $\left.10 \mathrm{nM} \mathrm{[}{ }^{3} \mathrm{H}\right] \mathrm{PK} 11195$ in buffer (fig. 2). Scatchard transformation of the saturation isotherm demonstrates maximal binding of $1120 \pm 65 \mathrm{fmol} / \mathrm{mg}$ protein to a single population of sites with a dissociation constant $\left(\mathrm{K}_{\mathrm{D}}\right)$ of $3.9 \pm 0.4 \mathrm{nM}$ (fig. 2 inset). Binding values were the same regardless of whether the sample had been purified over a cellulose column. The Hill coefficient for these peripheral-type binding sites is 1.1 suggesting no cooperativity between sites.

When the saturation experiments were carried out on membranes which were not entirely free of hemoglobin (preparation 2), $\quad \mathrm{B}_{\max }=522 \pm 13$ $\mathrm{fmol} / \mathrm{mg}$ protein while $\mathrm{K}_{\mathrm{D}}=2.8 \pm 0.7 \mathrm{nM}$ (data not shown). The maximal binding in 'preparation 2' membranes was significantly lower than $B_{\max }$ in 'preparation 1' membranes $(\mathrm{P}<0.005)$.

\subsection{Pharmacology of $\left[{ }^{3} \mathrm{H}\right] \mathrm{PK} 11195$ binding}

At peripheral-type binding sites described in other tissues, ligands bind with the following rank order of affinity: PK $11195 \simeq$ Ro 5-4864 > flunitrazepam $\gg$ clonazepam. Competition studies were carried out in which increasing concentrations of these ligands $(10 \mathrm{pM}-10 \mu \mathrm{M})$ compete with $2.5 \mathrm{nM}\left[{ }^{3} \mathrm{H}\right] \mathrm{PK} 11195$ for binding to erythrocyte membranes. $K_{I}$ values were $30 \mathrm{nM}$ for Ro 5-4864 and $70 \mathrm{nM}$ for flunitrazepam (where $\mathrm{K}_{\mathrm{I}}=\mathrm{IC}_{50} /\left(1+[\mathrm{PK} 11195] / \mathrm{K}_{\mathrm{D}}\right)$ from saturation experiments, data not shown). $K_{I}$ values could not be calculated for clonazepam because less than $50 \%$ of $\left[{ }^{3} \mathrm{H}\right] \cdot \mathrm{PK} 11195$ binding was inhibited by the maximal concentration of unlabeled clonazepam $(10 \mu \mathrm{M})$.

GMP-PNP (10 $\mu \mathrm{M})$, a non-hydrolyzable analog 
of GTP had no effect on either the affinity or maximal binding of $\left[{ }^{3} \mathrm{H}\right] \mathrm{PK} 11195$ binding (data not shown). Likewise, in the presence of $100 \mu \mathrm{M}$ $\mathrm{GABA}, \mathrm{K}_{\mathrm{D}}$ and $\mathrm{B}_{\max }$ values were not significantly different than control.

\section{Discussion}

Though the pharmacology of the peripheraltype benzodiazepine binding site has been well described, neither the function nor the subcellular distribution of the binding site has been clearly defined. The difficulty in obtaining nuclear, mitochondrial, and other cell fractions devoid of contaminants mitigates interpretation of fractionation studies in which compartment markers are not used (Laduron, 1977). For example, in fractionated rat adrenal, $\left[{ }^{3} \mathrm{H}\right] \mathrm{PK} 11195$ binding correlated well with the recovery of mitochondrial markers but shows no correlation with nuclear marker recovery even though $60 \%$ of $\left[{ }^{3} \mathrm{H}\right] \mathrm{PK} 11195$ binding was localized to the 'nuclear' fraction (Anholt et al., 1986). In other studies utilizing subcellular markers, peripheral-type benzodiazepine binding has been recovered in fractions rich in markers for sarcoplasmic reticulum and sarcolemma in canine myocardium (Doble et al., 1985).

Because human erythrocytes lack organelles, this study clearly demonstrates the presence of plasma membrane peripheral-type benzodiazepine binding sites in humans. It does not preclude the existence of intracellular binding sites in human cells which contain organelles. Erythrocytes extrude their nuclei and mitochondria before leaving the bone marrow. It is possible that upon extrusion of the mitochondria, part of the mitochondrial membrane may fuse with the plasma membrane and remain integrated in the erythrocyte. However, when erythrocyte membranes were assayed for MAO, a marker for the outer mitochondrial membrane, no clorgyline-sensitive activity was extracted suggesting that the benzodiazepine binding sites are not remnants of mitochondrial extrusion. It is highly unlikely that the binding described is due to leukocyte contamination because nucleated cells were absent or negligible in the preparations assayed.
Because human platelets bind peripheral-type ligands with high affinity (Benavides et al., 1984; Gavish et al., 1986), it was necessary to determine whether the observed binding was due to platelet contamination. Platelets maximally accounted for $0.012 \%$ of the protein assayed in our experiments. Using $\mathrm{B}_{\max }$ values for PK 11195 binding as reported by Benavides et al. (1984) it was determined that platelet contamination accounts for approximately $1.0 \%$ of the binding detected in our assays. Furthermore, when greater than $99 \%$ of the contaminating platelets were removed by cellulose columns, binding was within the standard deviation of binding to preparations containing $0.01 \%$ platelets. Taken together, these data suggest that the binding results reported in this paper are due to sites located on erythrocytes rather than platelets.

The $\mathrm{K}_{\mathrm{D}}$ values obtained by kinetic studies $(0.5$ $\pm 0.7 \mathrm{nM}$ ) and those obtained by equilibrium studies $(3.6 \pm 0.4 \mathrm{nM})$ are somewhat different. It is not clear whether this difference is due to technical reasons or whether some of the ligand may be trapped in membrane vesicles. Nevertheless, the affinity and rank order of ligands tested at the erythrocyte membrane binding site are similar to values reported in other systems for nanomolar affinity peripheral-type benzodiazepine binding sites (Schoemaker et al., 1983; Wang et al., 1980).

GABA potentiates binding of benzodiazepines to 'central' benzodiazepine binding sites, but does not alter binding to peripheral-type binding sites in tissues examined (Martin and Candy, 1978; Schoemaker et al., 1983). GMP-PNP, a non-hydrolyzable analog of GTP binds to the G proteins of the adenylate cyclase second messenger system. In receptor systems coupled to $G$ proteins, inclusion of GMP-PNP in binding assays causes a decrease in affinity for the agonist ligands which bind to the receptor (Anholt, 1986). Neither GABA nor GMP-PNP affected the binding parameters of the erythrocyte benzodiazepine binding site.

Hemin, isolated from human erythrocytes competitively inhibits mitochondrial benzodiazepine binding with a $\mathrm{K}_{\mathrm{I}}$ of $41 \mathrm{nM}$ (Verma et al., 1987). This may explain the decrease in $\mathbf{B}_{\max }$ in preparations containing small quantities of contaminating 
hemoglobin. Additionally, the contaminating hemoglobin is detected along with membrane protein in the Bradford assays. Since binding data is presented on a per $\mathrm{mg}$ basis, the presence of hemoglobin may artificially lower $B_{\max }$ values.

Starosta-Rubinstein et al. (1987) have demonstrated that high grade gliomas can be imaged in rat brain using radiolabeled peripheral-type benzodiazepine binding site ligands. Binding of these ligands to erythrocytes, platelets or other blood components must be taken into account when modeling human tumor imaging protocols after rat models.

The postulated functions for peripheral-type benzodiazepine binding sites are many (Anholt, 1986 for review). If hemin, carried by erythrocytes is indeed an endogenous ligand at the peripheral-type benzodiazepine binding sites (Verma et al., 1987), perhaps erythrocytic peripheral-type benzodiazepine binding sites are associated with regulation or transport of hemin. Alternatively, benzodiazepines (Ro 5-4864 > diazepam $>$ clonazepam $>$ oxazepam $>$ lorazepam $>$ flurazepam) inhibit both the uridine transport system and the site-specific binding of the nucleoside transport inhibitor, nitrobenzyl thioinosine (Hammond et al., 1983). Therefore, it is possible that the peripheral-type receptor is associated with a nucleoside transporter in human erythrocytes.

The function of peripheral-type benzodiazepine binding sites in human erythrocytes can only be postulated at this time. Subcellular distribution differences between tissues along with interspecies differences in macroscopic binding distribution suggest that benzodiazepine binding sites with similar peripheral type pharmacology may have different functions. It seems critical that until more is known about the peripheral-type site, questions of function should be examined independently in each tissue of interest.

\section{Acknowledgements}

We thank Zane Hollingsworth for technical assistance and Suyin Liang for manuscript preparation. This work was supported by USPHS Grant NS 15655 .

\section{References}

Anholt, R.R.H., 1986, Mitochondrial benzodiazepine receptors as potential modulators of intermediary metabolism, Trends Pharmacol. Sci. 7, 506.

Anholt, R.R.H., E.B. De Sousa, M.L. Oster-Granite and S.H. Snyder, 1985, Peripheral-type benzodiazepine receptors: autoradiographic localization in whole-body sections of neonatal rats, J. Pharmacol. Exp. Ther. 233, 517.

Anholt, R.R.H., P.L. Pedersen, E.B. De Sousa and S.H. Snyder, 1986, The peripheral-type benzodiazepine receptor: localization to the mitochondrial outer membrane, J. Biol. Chem. 261,576 .

Basile, A.S. and P. Skolnick, 1986, Subcellular localization of 'peripheral-type' binding sites for benzodiazepines in rat brain, J. Neurochem. 46, 305.

Benavides, J., D. Quarteronet, P.-F. Plouin, F. Imbault, T. Phan, A. Uzan, C. Renault, M.-C. Dubroeucq, C. Gueremy and G. Le Fur, 1984, Characterization of peripheral type benzodiazepine binding sites in human and rat platelets by using $\left[{ }^{3} \mathrm{H}\right] \mathrm{PK}$ 11195. Studies in hypertensive patients, Biochem. Pharmacol. 33, 2467.

Bentler, E., C. West and K.-G. Blume, 1976, The removal of leukocytes and platelets from whole blood, J. Lab. Clin. Med. 88, 328.

Braestrup, C. and R.F. Squires, 1977, Specific benzodiazepine receptors in rat brain characterized by high-affinity $\left[{ }^{3} \mathrm{H}\right] \mathrm{di}-$ azepam binding, Proc. Natl. Acad. Sci. U.S.A. 74, 3805.

Cymerman, U., A. Pazos and J.M. Palacios, 1986, Evidence for species differences in 'peripheral' benzodiazepine receptors: an autoradiographic study, Neurosci. Lett. 66, 153.

Doble, A., J. Benavides, O. Ferris, P. Bertrand, J. Menager, N. Vaucher, M.-C. Burgevin, A. Uzan, C. Gueremy and G. Le Fur, 1985, Dihydropyridine and peripheral type benzodiazepine binding sites: subcellular distribution and molecular size determination, European J. Pharmacol. 119, 153.

Doble, A., C. Malgouris, M. Daniel, N. Daniel, F. Imbault, A. Basbaum, A. Uzan, C. Gueremy and G. Le Fur, 1987, Labelling of peripheral-type benzodiazepine binding sites in human brain with $\left[{ }^{3} \mathrm{H}\right]$ PK 11195 : anatomical and subcellular distribution, Brain Res. Bull. 18, 49.

Dodge, J.T., C. Mitchell and D.J. Hanahan, 1963, The preparation and characterization of hemoglobin-free ghosts of human erythrocytes, Arch. Biochem. 100, 119.

Gavish, M., A. Weizman, L. Karp, S. Tyano and Z. Tanne, 1986, Decreased peripheral benzodiazepine binding sites in platelets of neuroleptic treated schizophrenics, European J. Pharmacol. 121, 275.

Hammond, J.R., S.M. Jarvis, A.R.P. Paterson and A.S. Clanachan, 1983, Benzodiazepine inhibition of nucleoside transport in human erythrocytes, Biochem. Pharmacol. 32, 1229.

Hampton, R.Y., F. Medzihradsky, J.H. Woods and P.J. Dahlstrom, 1982, Stereospecific binding of ${ }^{3} \mathrm{H}$-phencyclidine in brain membranes, Life Sci. 30, 2147.

Laduron, P., 1977, Tissue fractionation in neurobiochemistry: an analytical tool or a source of artifacts, Int. Rev. Neurobiol. 20,251 . 
Marangos, P.J., J. Patel, J.-P. Boulenger and R. Clark-Rosenberg, 1982, Characterization of peripheral-type benzodiazepine binding sites in brain using $\left[{ }^{3} \mathrm{H}\right] \mathrm{Ro} 5-4864$, Mol. Pharmacol. 22, 26.

Martin, I.L. and J.M. Candy, 1978, Facilitation of benzodiazepine binding by sodium chloride and GABA, Neuropharmacology 17, 993.

Pazos, A., U. Cymerman, A. Probst and J.M. Palacios, 1986, 'Peripheral' benzodiazepine binding sites in human brain and kidney: autoradiographic studies, Neurosci. Lett. 66, 147.

Ruff, M.R., C.B. Pert, R.J. Weber, L.M. Wahl, S.M. Wahl and S.M. Paul, 1985, Benzodiazepine receptor-mediated chemotaxis of human monocytes, Science 229, 1281.

Schoemaker, H., R.G. Boles, W.D. Horst and H.I. Yamamura, 1983, Specific high-affinity binding sites for $\left[{ }^{3} \mathrm{H}\right]$ Ro $5-4864$ in rat brain and kidney, J. Pharmacol. Exp. Ther. 225, 61.

Starosta-Rubinstein, S., B.J. Ciliax, J.B. Penney, P. McKeever and A.B. Young, 1987, Imaging of a glioma using peripheral benzodiazepine receptor ligands, Proc. Natl. Acad. Sci. U.S.A. 84, 891.

Taniguchi, T., J.K.T. Wang and S. Spector, 1980, Properties of $\left[{ }^{3} \mathrm{H}\right]$ diazepam binding to rat peritoneal mast cells, Life Sci. $27,171$.

Valtier, D., C. Malgouris, J.-C. Gilbert, P. Guicheny, A. Uzan, C. Gueremy, G. Le Fur, H. Saraux and P. Meyer, 1987, Binding sites for a peripheral type benzodiazepine antagonist $\left(\left[{ }^{3} \mathrm{H}\right] \mathrm{PK} 11195\right)$ in human iris, Neuropharmacology 26,549 .

Verma, A., J.S. Nye and S.H. Snyder, 1987, Porphyrins are endogenous ligands for the mitochondrial (peripheral-type) benzodiazepine receptor, Proc. Natl. Acad. Sci. U.S.A. 84, 2256.

Wang, J.K.R., T. Taniguchi and S. Spector, 1980, Properties of $\left[{ }^{3} \mathrm{H}\right]$ diazepam binding sites on rat blood platelets, Life Sci. $27,1881$.

Weissman, B.A., G.T. Bolger, L. Isaac, S.M. Paul and P. Skolnick, 1984, Characterization of the binding of $\left[{ }^{3} \mathrm{H}\right] \mathrm{Ro}$ 5-4864, a convulsant benzodiazepine, to guinea pig brain, $\mathrm{J}$. Neurochem. 42, 969.

Wurtman, R.J. and J. Axelrod, 1963, A sensitive and specific assay for the estimation of monoamine oxidase, Biochem. Pharmacol. 12, 1439. 